\title{
Reconsidering the Fundamental Problems of Vocational Education and Training in Turkey and Proposed Solutions for Restructuring
}

\author{
Mahmut Ozer ${ }^{1}$ (1)
}

\begin{abstract}
This study addresses the problems related to vocational education and training (VET) in Turkey through the perspective of global developments in VET and evaluates the steps that are taken in line with the solutions. From this perspective, increasing the private sector's role and share in VET, strengthening the general skills that support long-term VET graduate employment and that renounce specific specializations, and restructuring the capacity of VET to have a more realistic supply-and-demand relationship are suggested. Additionally, the indirect effect of primary education has been demonstrated, and decreasing the differences in academic achievement in primary education level has been emphasized as being able to lead to an increase in the number of students in VET with higher levels of academic and general skills.
\end{abstract}

\section{Keywords}

Vocational education and training • Employment • Workplace training • General education • Labor market 
Vocational Education and Training (VET) has an essential role in countries' economic development and employment policies. VET is affected by changes in economy and expectations from the labor market and transforms accordingly. Several comprehensive studies focused on VET development have been performed by international institutions due to the importance of VET (European Centre for the Development of Vocational Training [CEDEFOP], 2018; Organisation for Economic Co-operation and Development [OECD], 2010, 2014a, 2017; World Bank, 2019). Countries' economic conditions, technological capacities, and industrial tendencies directly affect the expectations from VET (World Bank, 2019). VET needs to have a dynamic structure in order to follow external changes and to react to the rapidly changing nature of technology and economic growth. This dynamic structure accompanies the changes and transformations in VET. Thus, the historical traces of VET also reflect countries' economic transformations. In other words, the footprints of countries' economic transformations can be indirectly tracked using these countries' VET transformations.

The VET process in Turkey shows similarities with current global trends in VET. VET has always maintained its importance in the Development Plans of Turkey (Devlet Planlama Teşkilatı [DPT]), and strengthening VET has been emphasized in these plans (DPT, 1963, 1967, 1972, 1979, 1985, 1989, 1996, 2001, 2007). Steps for strengthening VET have intensified, particularly in the VET-EU accommodation process. During this time, VET has been considered comprehensively, including in higher education levels, and numerous studies focused have been performed on modernization and the VET-EU accommodation (Günay \& Özer, 2014, 2016; Özer, Çavuşoğlu, \& Gür, 2011). Lately, the Ministry of National Education (MoNE) has developed and applied several projects for solving VET-related problems and for strengthening VET (MoNE, 2018a, 2018b, 2018c; Özer, 2018, 2019). VET is also a prominent and major subject in the Education Vision 2023 report, which MoNE (2018a) released in late 2018.

VET is considered a priority not just by the government in Turkey but also by the labor market, academia, civil society organizations, and think-tanks that have performed and released numerous research on VET (Aktaşl1, Kafadar, \& Tüzün, 2012; Aktaşlı \& Tüzün, 2012; Çelik, Yurdakul, Bozgeyikli, \& Gümüş, 2017; Günay \& Özer, 2014, 2016; Gür et al., 2012; Oral, 2012; Şencan, 2008; Türk Eğitim Derneği [TED], 1983). Thus consensus exists among MoNE, related institutions, and private sectors on strengthening VET. However, agreement on VET's importance does not guarantee accurate identification of VET-related issues and comprehensive discussions on the subject. Therefore, determining whether these issues are accurately identified or not is critical. Irrational perceptions toward VET can complicate the rational detection of VET-related issues. Inaccurate identification of issues decreases the effect of steps 
taken toward solutions, which may cause changes in unproblematic areas and invite new problems for VET. The inaccurate identification of problem-sources leads to the delay of solutions and, more importantly, to the iteration of issues that may cause stakeholders to be careless. Under these circumstances, the perception is reinforced of VET being an unsettled burden.

In this study, we discuss VET-related issues in Turkey and their backgrounds with the global conditions and developments in VET and propose solutions for these issues.

\section{Vocational Education and Training in Turkey}

VET at the secondary-school level includes various institutional structures and options in Turkey. VET is presented through two options: vocational-technical Anatolian high schools (VTAH) and vocational training centers (VTC). VTAH and VTC are both parts of the four-year compulsory high school-level education. VTAH is one type of academic education; however, VTS is considered a non-academic, vocational career path. VET is presented in 54 fields with 199 branches in VTAHs, and 27 fields with 143 branches in VTCs (MoNE, 2018b).

Two vocational programs are performed in VTAHs: the Anatolian technical program (ATP) and the Anatolian vocational program (AVP). ATP includes an intensely theoretical education program while AVP mainly presents students with applied training. In the four-year education-and-training period, students in ATPs intern for 40 days, while students in AVPs intern for three days each week in their final year. Students in ATPs are expected to continue on to higher education (MoNE, 2018b; Özer, 2019).

Students in VTCs take courses in schools one day a week and do on-the-job training at workplaces the other four days. Therefore, employers and enterprises make a great contribution to VTCs. Students who successfully complete their three years of education get a journayman's certificate and a certificate of mastership when they complete four years. In addition, VTC graduates need to successfully complete additional courses as specified by MoNE to earn a diploma (MoNE, 2018b).

The number of students in VET institutions in the last 10 years is given in Table 1 (Özer, 2019). As shown, the number of students in VET institutions has decreased in recent years, staying at the level of 2 million in the 2017-2018 academic year. In the 2017-2018 academic year, VET students constituted 35\% of all students at the secondary-school level in Turkey (MoNE, 2018b; Özer, 2018, 2019). VTC students also constituted 5\% of all students in VET institutions. 
Table 1

Number of Students in VET Institutions in the Last 10 Years

\begin{tabular}{|l|c|c|c|}
\hline Academic Year & $\begin{array}{c}\text { Number of Students in } \\
\text { Vocational-Technical } \\
\text { Anatolian High schools } \\
\text { (VTAHs) }\end{array}$ & $\begin{array}{c}\text { Number of Students in } \\
\text { Vocational Education } \\
\text { Centers } \\
\text { (VECs) }\end{array}$ & $\begin{array}{c}\text { Total Number of } \\
\text { Students }\end{array}$ \\
\hline $2017-2018$ & $1,886,246$ & 101,036 & $1,987,282$ \\
\hline $2016-2017$ & $1,969,776$ & 98,436 & $2,068,212$ \\
\hline $2015-2016$ & $2,007,806$ & 75,129 & $2,082,935$ \\
\hline $2014-2015$ & $2,043,492$ & 76,244 & $2,119,736$ \\
\hline $2013-2014$ & $1,944,020$ & 95,771 & $2,039,791$ \\
\hline $2012-2013$ & $2,176,702$ & 92,949 & $2,269,651$ \\
\hline $2011-2012$ & $1,978,705$ & 111,515 & $2,090,220$ \\
\hline $2010-2011$ & $1,952,478$ & 120,009 & $2,072,487$ \\
\hline $2009-2010$ & $1,654,532$ & 164,916 & $1,819,448$ \\
\hline $2008-2009$ & $1,378,667$ & 186,597 & $1,565,264$ \\
\hline
\end{tabular}

The number of graduates from VET institutions in the last 10 years is given in Table 2 (Özer, 2019). Table 2 shows the number of graduates from VET institutions to have had a continuous increase until 2017-2018, reaching a level of 400,000. The number of graduates from private VET institutions has also increased in recent years; however, the ratio of these graduates is still under $10 \%$.

Table 2

The Number of Graduates from VET Institutions in the Last 10 Years

\begin{tabular}{|l|c|c|c|c|}
\hline \multirow{2}{*}{ Academic Year } & \multicolumn{2}{|c|}{$\begin{array}{c}\text { Vocational-Technical Anatolian High } \\
\text { Schools (VTAHs) }\end{array}$} & $\begin{array}{c}\text { Vocational Training } \\
\text { Centers } \\
\text { (VTCs) }\end{array}$ & $\begin{array}{c}\text { Total Number of } \\
\text { VET Graduates }\end{array}$ \\
\cline { 2 - 5 } & $\begin{array}{c}\text { Public High } \\
\text { Schools }\end{array}$ & $\begin{array}{c}\text { Private High } \\
\text { Schools }\end{array}$ & 40,122 & 391,997 \\
\hline $2017-2018$ & 327,228 & 24,647 & 45,676 & 416,521 \\
\hline $2016-2017$ & 336,593 & 34,252 & 33,306 & 408,062 \\
\hline $2015-2016$ & 363,427 & 11,329 & 31,773 & 401,227 \\
\hline $2014-2015$ & 366,798 & 2,656 & 33,112 & 384,747 \\
\hline $2013-2014$ & 350,666 & 969 & 35,595 & 367,116 \\
\hline $2012-2013$ & 331,117 & 404 & 39,684 & 341,333 \\
\hline $2011-2012$ & 301,282 & 367 & 32,278 & 315,788 \\
\hline $2010-2011$ & 283,074 & 436 & 36,762 & 274,580 \\
\hline $2009-2010$ & 237,436 & 382 & 35,823 & 198,447 \\
\hline $2008-2009$ & 162,428 & 196 & & \\
\hline
\end{tabular}

\section{Employment for Vocational Education and Training Graduates}

According to the Turkish Statistical Institute (TurkStat) data, which can be seen in Table 3, the employment-and-labor force participation ratios for VET graduates 
are higher than general high school graduates (Özer, 2019). Table 3 shows the laborforce participation ratio for VET graduates to be $66.1 \%$ in 2018 while the ratio for general high school graduates is $54.2 \%$. Additionally, VET graduates' employment rate in 2018 was $57.4 \%$; this ratio was $46.7 \%$ for general high school graduates. In addition, the unemployment rate for VET graduates is approximately the same as for higher education graduates yet lower than for general high school graduates. TurkStat data shows that, contrary to expectations, the employment and labor-force participation rates for VET graduates are even higher than for general high school grads. This circumstance is also in line with the 10-year process for VET graduates from countries like Germany, Denmark, and Switzerland (Hanushek, Schwerdt, Woessman, \& Zhang, 2017; Hanushek, Woessman, \& Zhang, 2011). In these countries, VET students do on-the-job training in businesses in addition to being educated at school.

Table 3

Labor-Force Rates by Education Level (June, 2018)

\begin{tabular}{|l|c|c|c|}
\hline Education Level/Type & $\begin{array}{c}\text { Labour Force } \\
\text { Participation Ratio }\end{array}$ & Employment Ratio & $\begin{array}{c}\text { Unemployment } \\
\text { Ratio }\end{array}$ \\
\hline General High School & 54.2 & 46.7 & 13.9 \\
\hline Vocational and Technical High School & 66.1 & 57.4 & 13.1 \\
\hline Tertiary Education & 80.2 & 69.7 & 13.1 \\
\hline
\end{tabular}

MoNE also conducted research and published results on employment in and out of the area of education for VTAH graduates between 2008 and 2014 (MoNE, 2018b). Some examples of employment for VTAH graduates in and out of their fields are given in Table 4.

Table 4

Employment in and out of Their Area of Education for VTAH Graduates Between 2008-2014 (MoNE, 2018b)

\begin{tabular}{|l|c|c|}
\hline $\begin{array}{l}\text { Field } \\
\text { (Area of Profession) }\end{array}$ & $\begin{array}{c}\text { Ratio of VTAH Graduates } \\
\text { Employed in Their Field (\%) }\end{array}$ & $\begin{array}{c}\text { Ratio of VTAH Graduates } \\
\text { Employed out of Their Field } \\
\text { (\%) }\end{array}$ \\
\hline Transportation Services & 2.00 & 41.27 \\
\hline Aircraft Maintenance & 17.91 & 39.52 \\
\hline Textile Technology & 5.57 & 46.04 \\
\hline Agriculture & 1.73 & 35.15 \\
\hline Rail Systems Technology & 4.74 & 54.17 \\
\hline Plastic Technology & 3.7 & 53.07 \\
\hline Motor Vehicle Technology & 8.09 & 50.70 \\
\hline Metal Technology & 6.59 & 54.66 \\
\hline Machine Technology & 6.1 & 50.51 \\
\hline Laboratory Services & 18.28 & 55.76 \\
\hline Chemistry Technology & 1.89 & 46.31 \\
\hline Construction Technology & 7.85 & 42.58 \\
\hline Electric \& Electronic Technology & 9.30 & 44.83 \\
\hline Marine & 4.61 & 34.98 \\
\hline Biomedical Device Technology & 2.10 & 40.32 \\
\hline
\end{tabular}


As can be seen in Table 4, despite VTAH graduates having a comparatively high employment ratio, the employment rates for graduates in their fields are less than $10 \%$ in most fields (MoNE, 2018b; Özer, 2019). In other words, VTAH graduates tend to be employed out of their fields. Due to VTAH graduates being employed out of their fields, field-of-study mismatch issues arise (OECD, 2018).

Meanwhile, $88 \%$ of VTC graduates are employed in their field according to research conducted by MoNE (2019a). Additionally, 75\% of VTC graduates who are employed in their fields are also employed in institutions where students do onthe-job training. Sector delegates are impressed by VTC graduates' skills and have requested an increase in the capacity of VTCs. The high rate of students who are employed in their fields, even in institutions where students do on-the-job training, is an indicator of sector delegates' appreciation. VTC Students who perform intense and specific training on sector-requested vocational skills have a higher employment rate. VTC is accepted as a successful model for VET education when considering field of study and employability. VTC graduates' being employed more in their field (88\%) compared to VTAH graduates also indicates this consequence.

\section{Scale Issue in Vocational Education and Training}

The ratio of VET to academic education at the secondary-school level varies in different countries due to the differences in countries' economic structures. VET has mostly experienced two phases, and its scale is structured according to the experiences in these phases (Özer, 2019). In the first stages of economic development, the scale of VET enlarges, hence the ratio of VET to academic education increases. In the first phase where the scale of VET increases, technological development spreads to every facet of life, and the need for vocational expertise also increases. The scale of VET is enlarged to meet this need, and the knowledge and skills VET students gain present a relatively static profile in this phase. However, this ratio decreases in the second phase, where rapid developments in technology and economy are observed. In the second phase, the advantageous ratio of VET to academic education reverses (Bertocchi \& Spagat, 2004; Flora, 1983). In the second phase, developments in technological changes and the economy accelerate, with social transformation occurring concurrently. In this stage, the spread of technology within daily life has mostly been completed, and a new period with radical changes in technology begins. In this new period, the knowledge and skills that had been gained through traditional VET are no longer sufficient for meeting the needs of these radical changes, and traditional VET becomes a matter of doubt and discussion. Hence, in this second phase, the search and effort for VET always remain on the agenda (World Bank, 2019). 
Many countries have revived their VET systems to meet the needs of the second phase. Dramatic transformations also occur in the expectations and mission of general education and schools. In the second phase, schools are expected to prepare students during their education to work in jobs that don't even exist yet and to propose solutions for undefined problems with undiscovered products (Darling-Hammond, 2010). Furthering those discussions and contrary to the first phase, the scale of VET is tightened, and the ratio of general education, which concentrates on academic skills, increases (Bertocchi \& Spagat, 2004; Flora, 1983). With the changes in the mission of education, schools are considered as environments where students gain high levels of fundamental and academic skills that prepare graduates who can easily adapt to changing circumstances. In accordance with this, the World Bank has also increased the weight of primary schools in education projects and substantially decreased its project support on VET since the 1980s (Bennel \& Segerstrom, 1998).

One VET-related discussion in Turkey is about the ratio of VET to general education in secondary education. As mentioned earlier, VET students constituted $35 \%$ of students in secondary education level in the 2017-2018 academic year. A discourse repeated by sector delegates has been found for many years to increase this ratio. This discourse is based on the assumption that when the ratio of VET students increases, participation and concentration on university entrance examination will decrease. In other words, when the scale of VET is enlarged, VET graduates are thought to be able to be directly employed; hence, the pressure of the examinations on the education system will decrease. As I will mention in the following passages, these assumptions need to be discussed within a data-driven perspective. This discussion will be helpful in rationalizing assumption-based policies.

In the previous section, VTAH graduates' comparatively higher employment rates was mentioned, but they have quite low rates (less than $10 \%$ in most fields) for employment in their fields of education. VTAH graduates' high rate of out-offield employment also shows more VTAH graduates are found than are needed; this situation leads to the issue of skill surpluses. When skill surpluses occur, most graduates are employed out of their fields of education (field of study mismatch); consequently, graduates cannot use their knowledge or vocational skills optimally (OECD, 2018). Employing VTAH graduates in their fields seems to not be an issue that can be solved by enlarging the scale of VET. No concrete relationship exists between enlarging the scale of VET and eliminating field-of-study mismatch. On the contrary, a risk of reducing VET graduates' salaries exists with enlarging the scale of VET due to increases both in the number of VET graduates and the outof-field employment rates. This circumstance also leads to consolidating negative perceptions toward VET. 
VTAH graduates' out-of-field employment search is also directly related to the demand for higher education. The difference between VET graduates' and higher education graduates' salaries is higher in Turkey compared to other OECD countries. This circumstance keeps VTAH graduates' demand for higher education alive. Despite the fact that the placement ratio of VET graduates in higher education programs is quite low, their demand for higher education is maintained years after they graduate (Özer, 2018, 2019). Additionally, the number of applications to university entrance examinations still has an increasing trend and does not seem to be affected by the increasing ratio of VET graduates in the last 15 years. In this context, out-of-field employment may be chosen because it serves as a temporary employment opportunity and allows graduates to prepare for higher education. While the difference between starting salaries for VET graduates and higher education graduates persists, the demand for higher education does not seem to decrease, maybe even increasing when the ratio of VET to general education grows. In addition to the salary issue, this circumstance is also in line with the increasing expectations and tendencies of middle-class populations in many countries. In various countries, increasing income levels lead to the transformation of the expectations and gradual increase in demand for higher education from middle-class populations, who had mostly selected VET as a career path earlier (Chong, 2014).

Consequently, the scale of VET has to be determined in equilibrium with the supply and demand for skills instead of assumptions or inaccurate expectations.

\section{The Private Sector's Share in Vocational Education and Training}

One recent discussion about VET has been about the relationship of the increase in the private sectors' share with VET's educational quality, productivity, and sustainability. For instance, the World Bank suggests countries decrease their public expenditures toward VET and change VET's main location to the private sector (World Bank, 1995). The private sector's shares in VET in various countries have shown this approach to have become widespread around the world. For example, Germany, as an exemplary country for VET, has two of its three VET institutions private with $68 \%$ of the students studying in the private VET institutions in 2002 (Hippach-Schneider, Krause, \& Woll, 2007). Additionally, Holland has studied VET in 69 public and more than 100 private institutions at the secondary education level (OECD, 2014b).

The government in Turkey has prepared numerous incentive policies to motivate private sector delegates to be engaged in VET. Organized industrial zones, where various sectors are clustered, have been the focus of these incentive policies. To increase the private sector's share and participation in VET, Private Education 
Institutions Law No. 5580 was put into effect in 2012. Within this law, private VET institutions located in organized industrial zones are included within the scope of incentives. According to the law, private VET institutions located in organized industrial zones are financially supported by the government based on the number of students. The amount of financial support is determined annually by MoNE and the Ministry of Finance and Treasury jointly. Legal regulations have been applicable since the 2012-2013 academic year. In 2016, the law for private VET institutions located in organized industrial zones was extended so as to include private VET institutions not located in organized industrial zones. Thus, the government has supported all private VET institutions in proportion to the number of students since the 2016-2017 academic year (MoNE, 2018b, 2019a; Özer, 2019).

The number and ratio of students in private VET institutions between the 20082009 and 2017-2018 academic years in all VET institutions are given at Table 5. Table 5 shows the number and ratio of students in private VET institutions among all VET institutions to be quite low. In addition, incentives since the 2012-2013 academic year have contributed to increasing the private sector's share in VET. In the 2017-2018 academic year, 5.49\% of students in secondary VET school system study in private VET institutions through the contributions from government incentives. Even though, the private sector's share in VET is still quite low despite all the support and incentives.

Table 5

Number and Ratio of Private VET Institutions in the Secondary VET System for the Last 10 Years

\begin{tabular}{|l|c|c|c|}
\hline Academic Year & $\begin{array}{c}\text { Number of Students in } \\
\text { Private VET } \\
\text { Institutions }\end{array}$ & $\begin{array}{c}\text { Number of Students } \\
\text { in Secondary VET } \\
\text { System }\end{array}$ & $\begin{array}{c}\text { Ratio of Students in Private } \\
\text { VET Institutions to Stu- } \\
\text { dents in Secondary VET } \\
\text { System (\%) }\end{array}$ \\
\hline $2017-2018$ & 109,113 & $1,987,282$ & 5.49 \\
\hline $2016-2017$ & 111,720 & $2,068,212$ & 5.40 \\
\hline $2015-2016$ & 99,217 & $2,082,935$ & 4.76 \\
\hline $2014-2015$ & 75,890 & $2,119,736$ & 3.58 \\
\hline $2013-2014$ & 56,053 & $2,039,791$ & 2.75 \\
\hline $2012-2013$ & 17,854 & $2,269,651$ & 0.79 \\
\hline $2011-2012$ & 4,348 & $2,090,220$ & 0.21 \\
\hline $2010-2011$ & 1,951 & $2,072,487$ & 0.09 \\
\hline $2009-2010$ & 1,603 & $1,819,448$ & 0.09 \\
\hline $2008-2009$ & 1,379 & $1,565,264$ & 0.09 \\
\hline
\end{tabular}

Turkey's discussions on VET have mostly focused on the ratio of VET to general education; however, the private sector's share in VET has not been cited within the scope of these discussions. In other respects, the demand for increasing the scale of VET only being expressed for public institutions is extremely interesting. This circumstance beclouds the private sector's responsibility and burden for strengthening VET while leaving them out of discussion. Establishing VET institutions in the scope 
of and/or under the charge of the private sector is crucial for meeting the needs of the economy through VET. Consequently, strengthening the private sectors' participation is strongly needed to enhance the supply and demand in VET.

\section{Long-Term Employment Problem for VET Graduates}

Countries consider reviews and rankings in international academic achievement studies when revising and enhancing their education systems. Within this scope, international studies such as PISA and TIMSS present important and valuable information about the effects and outputs of these improvements, as well as countries' relative positions.

International assessments, aside from describing the current situation in education, focus on the general skills also requested by the labor market, the yield results for projections, and predictions. These assessments present information about how well students are prepared through the current education systems for the information society and for the challenges of the business world. For instance, Hanushek et al. $(2011 ; 2017)$ used the results from the OECD's International Adult Literacy Survey (IALS) to compare the employment statuses and salaries of VET graduates and general education graduates. The literacy test battery in IALS allows direct monitoring of cognitive skills in different age groups and school types (Hanushek et al., 2017). In the first stage after graduation, VET graduates have the advantage in employability; however, graduates of general education take the advantage as age increases. This change can be observed in all countries that present VET education, but is much more apparent in countries such as Germany, Denmark, and Switzerland where the workplace education model is predominantly applied (Hanushek et al., 2011).

The VET graduates in these countries are obviously more advantageous in employment between 16-26 years old. However, as age increases, VET graduates' advantage disappears and general education graduates have more advantages in employment (Hanushek et al., 2011). The mean IALS literacy scores for general education graduates is higher compared to VET graduates, particularly in Germany, and the difference between the two groups is even higher in older age groups (Hanushek et al., 2011). In Denmark, the mean IALS literacy scores for the two groups is similar at beginning levels; however, the mean IALS literacy scores for general education graduates become higher compared to VET graduates as age increases. VET graduates are employed at higher rates with the support of workplace training, but vocational skills become insufficient against the skills requested by the labor market in later stages as age increases. Accordingly, general education graduates have an important advantage in lifelong employment opportunities. Because the skills assessed in IALS 
are in line with the skills requested by the labor market, IALS results give great hints about lifelong employment patterns for both VET and general education graduates.

On the other hand, countries such as Finland, New Zealand, and the United Kingdom, where VET is mostly studied in school instead of the workplace, show no remarkable differences between the mean IALS literacy scores for general education graduates and VET graduates. The relationship between employment and age is also valid in these countries; however, the differences between these two groups are at minimal levels (Hanushek et al., 2011).

With the rapid technological changes, the value of skills gained in VET decreases faster than general abilities (Hanushek et al., 2007). Specifically, VET graduates' skills become useless due to the dynamic structural changes of occupations in fast growing economies (Hanushek, 2012). On the contrary, general skills in general education facilitate adapting to technological transformations and lead to decreased investment costs at later stages. Independent of technological transformation, general education leads to decreased investment costs through general skills and allows general education graduates to have better long-term employment opportunities (Hanushek et al., 2017).

Hanushek et al. (2017) also showed the decreased relative advantage of VET graduates in employment as age increases to also be valid for income levels. In other words, general education graduates' salaries are comparatively lower at the beginning stages, but this trend is reversed as age increases. This is obvious in countries such as Germany and Denmark, where VET is concentrated on workplace trainings. However, in Switzerland, which has a similar VET model, VET graduates are more advantageous in salary compared to general education graduates. This situation is explained by Switzerland's relatively low economic development compared to Germany or Denmark (Hanushek et al., 2017).

Consequently, workplace-centered VET allocates relatively low time and importance in developing general skills compared to general education. The difference between the two types of education manifests itself in lifelong employability and level of income.

\section{The Need for Restructuring VET to Ensure Long-Term Employment}

Countries that consider VET as an education type where academic skills can be gained to a limited extent, as a non-academic education, and as a career path may push themselves into a disadvantageous position in the long-term development process (Hanushek, 2012). Therefore, VET is in a restructuring process by strengthening and extending the scope of the general skills that modern economies need more. 
Restructuring VET decreases educational costs within the scope of lifelong learning and increases VET graduates' adaptability toward rapid technological changes.

In Turkey, VET students at the secondary education level begin vocational field education in $10^{\text {th }}$ grade and study branch education in $11^{\text {th }}$ and $12^{\text {th }}$ grades according to their field. VET at the secondary education level is served in 54 fields with 199 branches. When reviewing the branches under fields, focusing on the fields instead of branches is seen to be more prevalent and aimed at specialization in a field. This tendency was one of the general characteristics of VET in various countries, thus numerous curriculums and educational programs were developed according to the specific technical needs of the sector (Sahlberg, 2007). Indeed, when sector delegates expressed the profile they needed from VET graduates, they identified that this profile is appropriate only for the current processes and needs of their own companies (Hanushek, 2012). This situation may increase short-term sector appreciation; however, it restricts VET graduates' mobility between companies and decreases their adaptability toward long-term technological changes.

Global trends and transformations in VET show academic and general skills to be more comprehensively included in the education process and extensive VET fields to have been structured instead of specific braches. Flexible mobility between professions and strengthening the learning ability are inevitable characteristics of the new VET structuring processes (Sahlberg, 2007). Nowadays, Turkey is in the third phase of VET, and automation has becomes widespread and supported by artificial intelligence (AI) technologies in this phase (Perc, Özer, \& Hojnik, 2019). According to the Phase III needs, the skills gained through VET are not alternatives for general skills; on the contrary, they become an integral part of general skills. This transformation, which is supported by automation and AI, has led to a negative effect on employment (displacement effect) but also to new skills for new business lines (Acemoğlu \& Restrepo, 2018). Including these skills in VET and strengthening graduates' academic skills and general skills to enhance these skills will lead to enhancing VET graduates' long-term employability.

\section{Student Entrance to Vocational Education and Training}

In most OECD countries, youths perceive VET as a low-status type of education and consider it as their second or third option (Sahlberg, 2007). Related discussions show current anti-VET perceptual issues to exist in almost all countries (Cedefop, 2018; Chong, 2014; Pilz, 2017). A common complaint is found about the high schooldropout and absenteeism rates in VET institutions (Abusland, 2014; Cedefop, 2018; European Quality Assurance in Vocational Education and Training [EQAVET], 2015; Waltzer \& Bire, 2014; Vantuch \& Jelinkova, 2013). Countries allocate remarkable 
efforts to enhance the perceptions toward VET and to produce solutions within education systems.

Student perceptions and preferences towards VET in Turkey do not differ from global trends and developments. However, external and systematic interventions that directly affect VET have also been conducted in Turkey. Regulations such as the coefficient rule, which makes VET graduates' transition to higher education more difficult, increased the VET problem in Turkey, which had already had its mentioned problems. Negative impacts from the coefficient rule accompanied VET for many years in Turkey (Özer, 2018, 2019; Özer, Çavuşoğlu, \& Gür, 2011). In addition, students' placement in high schools, which had been performed through their scores on the central exam between 2014 and 2017, led to students with high academic achievement being placed in science high schools, social sciences high schools, and Anatolian high schools. Thus, students with comparatively low academic achievement were mostly clustered in VET institutions between these years (Çelik, Boz, Arkan, \& Toklucu, 2017; Özer, 2019). The reflection and outcomes of this circumstance can be seen in the score differences between school types in the results of international academic achievement studies. For example, the results from PISA 2015 are given in Table 6 with respect to school type and level in Turkey (MoNE, 2016).

Table 6

PISA 2015 Mean Literacy Scores with Respect to School Type and Level in Turkey

\begin{tabular}{|l|c|c|c|c|c|c|c|}
\hline Literacy & $\begin{array}{c}\text { Science } \\
\text { High } \\
\text { Schools }\end{array}$ & $\begin{array}{c}\text { Social } \\
\text { Sciences } \\
\text { High Schools }\end{array}$ & $\begin{array}{c}\text { Anatolian } \\
\text { High } \\
\text { Schools }\end{array}$ & $\begin{array}{c}\text { Anatolian } \\
\text { Imam } \\
\text { Hatip High } \\
\text { Schools }\end{array}$ & $\begin{array}{c}\text { Arts } \\
\text { High } \\
\text { Schools }\end{array}$ & $\begin{array}{c}\text { Vocational } \\
\text { \& Technical } \\
\text { Anatolian } \\
\text { High Schools }\end{array}$ & $\begin{array}{c}\text { Multiple } \\
\text { Program } \\
\text { High } \\
\text { Schools }\end{array}$ \\
\hline Reading & 524 & 523 & 464 & 413 & 408 & 396 & 385 \\
\hline Science & 534 & 518 & 461 & 407 & 405 & 392 & 388 \\
\hline Mathematics & 537 & 504 & 454 & 398 & 373 & 391 & 379 \\
\hline
\end{tabular}

When considering that a 30-point score difference is equal to one year of education, VET students' reading-, science-, and math-literacy levels are quite low compared to students from other high school types (Atmaca, 2018). This consequence affects the demand of students with higher academic achievement for VET and worsens the negative perception towards VET. Additionally, school dropouts and absenteeism are thought to be affected by this circumstance (Özer, 2018, 2019). One of the challenges faced by VET in Turkey is that expectations from VET have increased; however, students with higher achievement levels do not prefer VET at the same time.

These results show that the issues in these mentioned areas have not been solved in primary education and translate to the high school level; the issues become more apparent due to clustering students according to their academic achievement levels. In this context, VET is the education type that suffers at the maximum level from issues in primary education. Without this reality, searching for the source of the issues 
and spending efforts on solutions in the context of VET will not be effective and will postpone solutions because these efforts ignore the issues' real source.

\section{Conclusion \& Discussion}

VET-related issues are observed to have great similarities in most countries. Increases in economic development and readily transitioning to higher education have led to changes in students' preferences and increased the percentage of students who select general education. VET is perceived as students' second choice and has become the destination for students with lower academic achievement levels. As mentioned, VET is in a new phase with the economic developments and rapid changes in technology. The most challenging issue VET faces is that expectations from VET have increased despite the fact that students with comparatively low academic achievement levels are clustered in VET institutions.

In this respect, the VET-related issues in Turkey show similarities with global VET-related issues. However, negative external interventions such as the coefficient rule have caused a traumatic process for VET, which had already gone through a problematic phase all over the world. Despite the numerous improvements made to end this traumatic process, the damage has not been recovered from completely. Furthermore, the issue of differences in academic achievement between schools and regions has not been solved adequately in primary education, and this issue has been transferred to the high school level. As the PISA results show, a chronic academic achievement difference between high school types has arisen due to this translated issue. Vocational and Technical Anatolian High Schools (VTAHs) have been affected by this negative circumstance at the maximum level. MoNE recently attempted to establish a new type of VET school with very strong companies such as ASELSAN and with top universities such as Istanbul Technical University (Özer, 2019). Secondary school placement results show the new type of VET schools for the first time to receive students from the top 1\% (MoNE, 2019b). In addition, MoNE (2018a) has specified minimizing the academic achievement differences between school types as a main objective in the Education Vision 2023. Improvements in this context will lead to increases in education quality and in the academic achievement levels students input to VET, and hence in the capacity to train graduates with qualified expectations of the labor market.

Contrary to global tendencies, the private sector's share in VET has been quite low (less than 6\%) in Turkey, despite government incentives. Therefore, the private sector needs to invest more in VET. Although the private sector in Turkey is entitled to establish Vocational and Technical Anatolian High Schools (VTAHs), the sector has no legal right to establish Vocational Training Centers (VTCs). Despite VTAH 
graduates mostly preferring to work outside of their field of education, VTC graduates' employment rate in their field of education (88\%) shows an opportunity exists for capacity increase. To solve this problem and increase the share and participation of the private sector in VTCs, the Private Education Institutions Law No. 5580 has been enacted very recently. According to this law, the private sector can establish VTCs. A remarkable improvement for strengthening VET in Turkey will be made thanks to this law. The private sectors' establishment of VTCs will lead to strengthening VET in Turkey, and the private sector will be able to train the workforce it needs. In addition, MoNE made a new regulation allowing students to complete additional courses earn a diploma when they come to school one day a week. This new regulation will also have a potential to increase the demand for VTCs.

Meanwhile, a remarkable inconsistency is observed between VET fields in public schools and sector fields at the region and province levels (MoNE, 2019; Özer, 2019). Therefore, VET institutions and fields have to be aligned with the sector countrywide. In other words, VET education fields have to be reorganized and oriented according to sector fields, and capacities have to be determined according to employment opportunities. A supply-and-demand orientation will positively affect and rationalize the supply-and-demand relationship with VET. Otherwise, an imbalance of supply and demand will lead to skill surpluses and field-of-study mismatches (OECD, 2018).

Many countries conduct campaigns to improve the perceptions toward VET, to abandon specific specializations, to identify skills more comprehensively, and to concentrate on general skills. The new approach has eased mobility between professions, provided VET graduates with the ability to adapt to technological changes, and improved VET graduates' abilities to develop long-term skills. This transformation is also in line with the skills the labor market demands in an environment where automation has become widespread. These skills will ease VET graduates' adaptability to change and increase their resilience towards technological changes, which are an output of rapid economic development. Within this scope, simplifying VET fields and branches by considering the current situation of the labor market and increasing the share of general skills in VET are suggested. Accordingly, simplifying the branches under fields, structuring the VET mostly on fields, and including more academic and general skills to VET programs will improve VET graduates' educational quality and employability. These practices will strengthen both their short-term employment as well as their long-term employment potentials. Concurrently, the cost of life-long learning and mobility between professions will decrease. 


\section{Acknowledgements}

The author declares no potential conflicts of interest with respect to the research, authorship, and/or publication of this article.

The author received no financial support for the research, authorship, and/or publication of this article.

\section{References}

Abusland, T. (2014). Early leaving from vocational education and training: United Kingdom. UK: UK NARIC, ECCTIS.

Acemoğlu, D., \& Restrepo, P. (2018). Artificial intelligence, automation and work (NBER Working Paper 24196). Cambridge, MA: National Bureau of Economic Research.

Aktaşl1, İ., \& Tüzün, I. (2012). Mesleki ve teknik eğitimde kalite strateji belgesi [Quality strategy certificate in vocational and technical education]. İstanbul, Turkey: Eğitim Reformu Girişimi.

Aktaşl1, İ., Kafadar, S., \& Tüzün, I. (2012). Meslek eğitiminde kalite için işbirliği: Meslekî ve teknik eğitimde güncellenmiş durum analizi [Collaboration for quality in vocational education: Updated situation analysis in vocational and technical education]. İstanbul, Turkey: Eğitim Reformu Girişimi.

Atmaca, T. (2018). Eğitimde eşitlik yanılsaması: Türkiye'de eğitimde eşitsizliklerin yeniden üretimi [Illusion of equality in education: Reproduction of inequalities in education in Turkey]. In L. Sunar (Ed.), Türkiye'de toplumsal tabakalaşma ve eşitsizlik [Social stratification and inequality in Turkey] (pp. 215-254). Ankara, Turkey: Nobel Akademik Yayıncılık.

Bennel, P., \& Segerstrom, J. (1998). Vocational education and training in developing countries: Has the World Bank got it right? International Journal of Educational Development, 18(4), 271-287.

Bertocchi, G., \& Spagat, M. (2004). The evolution of modern educational systems: Technical vs. general education, distributional conflict, and growth. Journal of Development Economics, 73, 559-582.

Çelik, Z., Boz, N., Arkan, Z., \& Toklucu, D. K. (2017). TEOG yerleştirme sistemi: Güçlükler ve öneriler [TEOG placement system: Difficulties and suggestions]. Ankara, Turkey: Siyaset, Ekonomi ve Toplum Araştırmaları Vakfı.

Çelik, Z., Yurdakul, S., Bozgeyikli, H., \& Gümüş, S. (2017). Eğitime bakış 2017: İzleme ve değerlendirme raporu [Education overview 2017: Monitoring and evaluation report]. Ankara, Turkey: Eğitim Bir-Sen Stratejik Araştırmalar Merkezi.

Chong, T. (2014). Vocational education in Singapore: Meritocracy and hidden narratives. Discourse: Studies in the Cultural Politics of Education, 35(5), 637-648.

Darling-Hammond, L. (2010). The Flat World and education: How America's commitment to future equity will determine our future. New York, NY: Teachers College, Columbia University.

Devlet Planlama Teşkilatı. (1963). I. Beş yıllık kalkınma planı [I. Five-year development plan]. Ankara, Turkey: Author.

Devlet Planlama Teşkilatı. (1967). II. Beş yıllık kalkınma planı [II. Five-year development plan]. Ankara, Turkey: Author. 
Devlet Planlama Teşkilatı. (1972). III. Beş yıllık kalkınma planı [III. Five-year development plan]. Ankara, Turkey: Author.

Devlet Planlama Teşkilatı. (1979). IV. Beş yıllık kalkınma planı [IV. Five-year development plan]. Ankara, Turkey: Author.

Devlet Planlama Teşkilatı. (1985). V. Beş yıllık kalkınma planı [V. Five-year development plan]. Ankara, Turkey: Author.

Devlet Planlama Teşkilatı. (1989). VI. Beş yıllık kalkınma planı [VI. Five-year development plan]. Ankara, Turkey: Author.

Devlet Planlama Teşkilatı. (1996). VII. Beş yıllık kalkınma planı [VII. Five-year development plan]. Ankara, Turkey: Author.

Devlet Planlama Teşkilatı. (2001). VIII. Beş yıllık kalkınma planı [VIII. Five-year development plan]. Ankara, Turkey: Author.

Devlet Planlama Teşkilatı. (2007). IX. Beş yıllık kalkınma planı [IX. Five-year development plan]. Ankara, Turkey: Author.

European Quality Assurance in Vocational Education and Training. (2015). Actions to reduce early leaving in vocational education and training (Policy Brief). Retrieved from https://www.eqavet. eu/Eqavet2017/media/Documents/EQAVET-Policy-Brief-on-PLA-on-Actions-to-reduce-earlyleaving-in-VET.pdf

European Centre for the Development of Vocational Training. (2018). The changing nature and role of vocational education and training in Europe. Vol. 3: the responsiveness of European VET systems to external change (1995-2015) (Cedefop Research Paper, No 67). Luxemburg: Author.

Flora, P. (1983). State, economy, and society in Western Europe 1815-1975. A data handbook. The growth of mass democracies and welfare states. Chicago, IL: St. James Press.

Günay, D., \& Özer, M. (2014). Türkiye'de meslek yüksekokullarl, mevcut durum, sorunlar ve çözüm önerileri [Vocational schools in Turkey, the current situation, problems and solutions]. Ankara, Turkey: Yükseköğretim Kurulu.

Günay, D., \& Özer, M. (2016). Türkiye'de meslek yüksekokullarının 2000'li yıllardaki gelişimi ve mevcut zorluklar [The development of Turkish post-secondary vocational colleges in the 2000's and the current challenges]. Yüksekögretim ve Bilim Dergisi, 6(1), 1-12.

Gür, B. S., Özoğlu, M., Akgeyik, T., Çetinkaya, E., Karagöl, E. T., Öztürk, M. ... Çelik, Z. (2012). Türkiye'nin insan kaynağının belirlenmesi [Determination of Turkey's human resources]. Ankara, Turkey: Siyaset, Ekonomi ve Toplum Araştırmaları Vakfı.

Hanushek, E. A. (2012). Dual education: Europe's secret recipe? CESifo Forum, 13(3), 29-34.

Hanushek, E. A., Schwerdt, G., Woessman, L., Zhang, L. (2017). General education, vocational education, and labor-market outcomes over the life-cycle. The Journal of Human Resources, 52(1), 48-87.

Hanushek, E. A., Woessman, L., \& Zhang, L. (2011). General education, vocational education, and labor-market outcomes over the life-cycle (NBER Working Paper 17504). Cambridge, MA: National Bureau of Economic Research.

Hippach-Schneider, U., Krause, M., Woll, C. (2007). Vocational education and training in Germany: Short description (CEDEFOP Panorama Series: 138). Retrieved from https://www. cedefop.europa.eu/files/5173_en.pdf 
Ministry of National Education. (2016). PISA 2015 ulusal raporu [PISA 2015 national report]. Ankara, Turkey: Author.

Ministry of National Education. (2018a). Güçlü yarınlar için 2023 eğitim vizyonu [2023 education vision for strong tomorrows]. Ankara, Turkey: Author.

Ministry of National Education. (2018b). Ĕgitim analiz ve değerlendirme raporlart serisi No: 1. Türkiye'de mesleki ve teknik eğitimin görünümü [Education analysis and evaluation report series No. 1. In view of the vocational and technical education in Turkey]. Ankara, Turkey: Author.

Ministry of National Education. (2018c). Eğitim analiz ve değerlendirme raporlart serisi No: 2. Mesleki ve teknik ortä̈gretimde kurumsal diş değerlendirme raporu [Education analysis and evaluation report series No. 2. Institutional external evaluation report in vocational and technical secondary education]. Ankara, Turkey: Author.

Ministry of National Education. (2019a). Eğitim analiz ve değerlendirme raporlarl serisi No: 6 . Organize sanayi bölgelerinde mesleki ve teknik eğitim [Education analysis and evaluation report series No. 6. Vocational and technical training in organized industrial zones]. Ankara, Turkey: Author.

Ministry of National Education. (2019b). Eğitim analiz ve değerlendirme raporlart serisi No: 8 . 2019 Liselere Geçiş Sistemi (LGS) kapsamında ilk yerleştirme sonuçları [Education analysis and evaluation report series No. 8. 2019 first placement results within the scope of high school transition system (LGS)]. Ankara, Turkey: Author.

Oral, I. (2012). Mesleki eğitimde ne çalışlyor, neden çalışlyor: Okul işletme iş birliklerine dair politika önerileri [What works and why does it work in vocational education: Policy recommendations for school business partnerships]. İstanbul, Turkey: Eğitim Reformu Girişimi.

Özer, M. (2018). 2023 eğitim vizyonu ve mesleki ve teknik eğitimde yeni hedefler [The 2023 education vision and new goals in vocational and technical education]. Yüksekögretim ve Bilim Dergisi, 8(3), 425-435.

Özer, M. (2019). Mesleki ve Teknik eğitimde sorunların arka planı ve Türkiye'nin 2023 Eğitim Vizyonunda Çözüme yönelik yol haritası [Background of problems in vocational education and training and its road map to solution in Turkey's education vision 2023]. Yüksekögrretim ve Bilim Dergisi, 9(1), 1-11.

Özer, M., Çavuşoğlu, A., \& Gür, B. S. (2011). Restorasyon ve toparlanma dönemi: Mesleki ve teknik eğitimde 2000'li yıllar [Restoration and recovery period: 2000 s in vocational and technical education]. In B. S. Gür (Ed.), 2000'li Ylllar: Türkiye'de Eğitim [2000s: Education in Turkey] (pp. 163-192). İstanbul, Turkey: Meydan.

Perc, M., Ozer, M., \& Hojnik, J. (2019). Social and juristic challenges of artificial intelligence. Palgrave Communications, 5, 61. | https://doi.org/10.1057/s41599-019-0278-x

Pilz, M. (2017). Vocational education and training in times of economic crisis: Lessons from around the World. Manhattan, NY: Springer International Publishing.

Sahlberg, P. (2007). Secondary education in OECD countries: Common challenges, differing solutions. Torino, Italy: European Training Foundation.

Şencan, H. (2008). Türkiye'de meslekî ve teknik eğitim: Sorunlar ve öneriler [Vocational and technical education in Turkey: Problems and suggestions]. İstanbul, Turkey: Tavaslı Matbaacılık.

The Organisation for Economic Co-operation and Development. (2010). Learning for jobs. OECD reviews of vocational education and training: Options for China. Paris, France: Author. 
The Organisation for Economic Co-operation and Development. (2014a). OECD reviews of vocational education and training: Key massages and country summaries. Paris, France: Author.

The Organisation for Economic Co-operation and Development. (2014b). A skills beyond school review of the Netherland. Paris, France: Author.

The Organisation for Economic Co-operation and Development. (2017). Education policy outlook: Austria. Paris, France: Author.

The Organisation for Economic Co-operation and Development. (2018). Skills for jobs. Paris, France: Author.

Türk Eğitim Derneği. (1983). Türkiye’de meslek eğitimi ve sorunlart. VI. Eğitim toplantısı [Vocational training and problems in Turkey. VI. Training meeting]. Ankara, Turkey: Author.

Vantuch, J., \& Jelinkova, D. (2013). Early leaving from vocational education and training in Slovakia. Bratislava: SIOV/SNO. Retrieved from http://www.refernet.sk/images/news/files/ Early\%20leaving\%20from\%20VET\%20in\%20Slovakia.pdf

Waltzer L., \& Bire, M. (2014). Early leaving from vocational education and training: Luxembourg. Luxembourg, INFPC. Retrieved from https://cms.refernet.lu/View/Document/early-leavingschool/en

World Bank. (1995). Priorities and strategies for education: A World Bank sector review. Washington, DC: Education and social policy department.

World Bank. (2019). The changing nature of work. World development report. Washington, DC: International Bank for Reconstruction and Development. 
